\title{
Penggalian Kriteria Vendor Teknologi Informasi di Pondok Pesantren Mojokerto Jawa Timur Berdasarkan Metode Analytic Network Process
}

\author{
Defit Setya Ike, Bekti Cahyo Hidayanto, Hanim Maria Astuti \\ Jurusan Sistem Informasi, Fakultas Teknologi Informasi, Institut Teknologi Sepuluh Nopember (ITS) \\ Jl. Arief Rahman Hakim, Surabaya 60111 Indonesia \\ e-mail: bekticahyo@its-sby.edu, hanim@its-sby.edu, setyaaljundy@gmail.com,
}

\begin{abstract}
Abstrak-Pemilihan perangkat teknologi informasi harus dilakukan secara tepat dan cermat agar menghasilkan perangkat TI yang berkualitas. Pembelian perangkat teknologi informasi di pondok pesantren pada umumnya masih berdasarkan pada ketersediaan dana belum berdasarkan atas pemilihan yang bersifat kompleks (multi kriteria). Sehingga hanya membeli perangkat TI dengan harga yang murah tanpa melihat aspek dan kriteria lainnya. Dalam hal ini dibutuhkan studi penggalian kriteria berdasarkan metode pemilihan untuk menentukan vendor TI yang mempunyai kriteria terbaik. Salah satu metode yang dapat diaplikasikan adalah pemilihan vendor TI berdasarkan multi kriteria adalah menggunakan metode Analytic Network Process. Dari hasil studi penggalian kriteria yang dilakukan pada 3 pondok pesantren di Mojokerto Jawa Timur terdapat 5 kriteria utama yang mempunyai nilai tingkat kepentingan tertinggi yaitu harga dengan nilai kepentingan 9, kualitas produk 9, garansi 8.33, spesifikasi 7.33 dan fasilitas yang diberikan oleh vendor dengan nilai tingkat kepentingan 7 . Sedangkan untuk kriteria yang menjadi harapan antara lain predikat vendor dan pamor atau vendor dikenal luas oleh khalayak.
\end{abstract}

Kata kunci-Metode Analytic Network Process (ANP), Multicriteria Decision Making (MCDM), Pondok Pesantren, Vendor TI

\section{PENDAHULUAN}

$\mathrm{P}$ ONDOK pesantren merupakan penyelenggara layanan pendidikan yang sudah tidak kalah dengan instansi pendidikan formal lainnya. Model sistem pendidikan yang diterapkan di pondok pesantren terdapat dua model yaitu sistem pendidikan modern dan sistem pendidikan tradisional. Hal tersebut terjadi karena adanya ekspansi pendidikan modern zaman penjajahan Belanda saat itu yang selanjutnya direspon dengan cara menolak sembari mencontoh modernitas untuk kontinuitas dan kelangsungan proses pendidikan di pondok pesantren [1]. Dari waktu ke waktu pondok pesantren terus berbenah diri dan siap bersaing dengan dengan sekolah-sekolah pada umumnya, baik dari segi kualitas sekolah maupun kuantitas anak didik mereka. Guna mendukung proses belajar mengajar yang sudah mulai meninggalkan metode tradisional, diperlukan adanya teknologi informasi yang berupa unit komputer dan sejenisnya yang dapat mendukung kebutuhan proses informasi pada sebuah organisasi. Teknologi Informasi dilingkungan pondok pesantren belum maju pesat seperti sekolah umum yang berbasis teknologi informasi. Namun seiring dengan perkembangan dan kebutuhan terhadap teknologi informasi. Pondok pesantren mulai membuka diri untuk memakai dan mengembangkan teknologi informasi. Untuk memenuhi kebutuhan teknologi informasi tersebut dibutuhkan adanya pembelian TI berdasarkan vendor tertentu. Teknologi informasi yang dibutuhkan berupa perangkat keras maupun perangkat lunak yang kemudian akan menghasilkan keuntungan untuk instansi pondok pesantren. Dengan adanya TI tersebut diharapkan pondok pesantren dapat meningkatkan kualitas layanan, meningkatkan kualitas semangat kerja dan menghemat waktu dibandingkan dengan metode tradisional yaitu menggunakan kertas untuk kebutuhan administrasi dan menggunakan kapur tulis, spidol dan papan tulis untuk proses kegiatan belajar mengajar.

Dalam menginvestasikan sebagian dana untuk membeli seperangkat teknologi informasi yang berupa perangkat kebutuhan proses bisnis dan belajar mengajar seperti laptop, komputer, LCD proyektor dan lain sebagainya, pihak pondok pesantren harus mempunyai pertimbangan-pertimbangan lain selain ketersediaan dana. Pihak pembuat keputusan mengidentifikasi terlebih dahulu seperti apa kebutuhan teknologi informasi yang akan diterapkan disana. Mereka perlu mendefinisikan seperti apa kriteria perangkat teknologi informasi yang akan dipilih oleh pondok pesantren tersebut. Untuk itu, diperlukan adanya penggalian kriteria pemilihan vendor TI di pondok pesantren. Penggalian kriteria ini dilakukan di beberapa pondok pesantren di Mojokerto dengan cara penyebaran kuesioner. Dengan adanya proses tersebut didapatkan 5 kriteria utama yang mempunyai nilai tingkat kepentingan tertinggi yaitu harga dengan nilai kepentingan 9, kualitas produk 9, garansi 8.33, spesifikasi 7.33 dan fasilitas yang diberikan oleh vendor dengan nilai tingkat kepentingan 7 . Sedangkan untuk kriteria yang menjadi harapan antara lain predikat vendor dan pamor atau vendor dikenal luas oleh khalayak.

\section{TINJAUAN PUSTAKA}

\section{A. Studi Sebelumnya}

Penggunaan metode Analytic Network Process dalam pemilihan vendor atau supplier tertentu untuk suatu instansi tertentu sudah banyak digunakan. Metode ini digunakan untuk 
memilih satu vendor terbaik berdasarkan sejumlah kriteria yang dimiliki oleh vendor tersebut. Dengan menggunakan metode ANP akan diidentifikasi keterkaitan antar kriteria yang akan menghasilkan keputusan yang terbaik [2].

PT KRA akan melakukan pemilihan vendor spare part misalnya, pihak pengambil keputusan akan melakukan pemilihan vendor yang tepat untuk intansinya. Proses pemilihan ini harus memperhatikan sejumlah kriteria baik kriteria yang sudah ditentukan atau kriteria yang akan muncul pada masa berikutnya. Sejumlah kriteria tersebut diantaranya kualitas, biaya, kapasitas produk, fasilitas yang ditawarkan, dan pengalaman dari masing-masing vendor [3].

\section{B. Dasar Teori}

1) Vendor

Pengertian vendor dalam Kamus Besar Bahasa Indonesia adalah orang yang menjual rumah, tanah dan sebagainya dapat diartikan juga sebagai penjual [4]. Vendor merupakan lembaga, perorangan atau pihak ketiga yang menyediakan bahan, jasa, produk untuk diolah atau dijual kembali atau dibutuhkan oleh perusahaan untuk meningkatkan kinerja perusahaan.

2) Pondok Pesantren

Menurut pendapat para ilmuwan, istilah pondok pesantren adalah merupakan dua istilah yang mengandung satu arti. Orang jawa menyebutnya "pondok" atau "pesantren". Sering pula menyebut sebagai pondok pesantren. Istilah pondok barangkali berasal dari pengertian asrama-asrama para santri yang disebut pondok atau tempat tinggal yang terbuat dari bambu atau barangkali berasal dari bahasa Arab "funduq" artinya asrama besar yang disediakan untuk persinggahan.

\section{3) Multicriteria Decision Making (MCDM)}

Pengambilan keputusan (Decision Making) adalah proses studi atau pembelajaran untuk mengidentifikasi dan memilih alternatif berdasarkan nilai dan pilihan dari pembuat keputusan. Dalam proses pembuatan keputusan secara langsung terdapat beberapa alternatif dan pilihan yang dapat dipertimbangkan. Sedangkan Multi Criteria Decision Making (MCDM) adalah sebuah proses menentukan sebuah pilihan dari berbagai alternatif atau pilihan yang tersedia

4) Metode Pengambilan Keputusan

Ada beberapa metode dalam pengambilan keputusan dengan beberapa kriteria dalam pemilihan Vendor TI, diantaranya adalah Cluster Analysis, model statistik, Decision Support System (DSS), Activity Based Costing (ABC), Total Cost of Ownership Models (TCOM), namun yang paling sering digunakan adalah Analytic Herarchy Process (AHP) dan Analytic Network Process (ANP). Dalam kasus ini, metode yang digunakan adalah Analytic Network Process.

\section{5) Analytic Network Proocess}

Analytic Network Process merupakan metode yang menghasilkan kerangka kerja untuk mengatasi permasalahan pengambilan keputusan tanpa membuat asumsi yang berkaitan dengan independensi antara level elemen yang lebih tinggi dengan yang lebih rendah dan independensi dari elemen-elemen dalam satu level. Metode ini merupakan metode hasil pengembangan dari Analytic Hierarchy Process (AHP) yang dikembangkan oleh Thomas Saaty. Analytic Network Process (ANP) menggunakan network tanpa penjelasan yang spesifik tentang level-level yang ada seperti pada suatu hirarki.

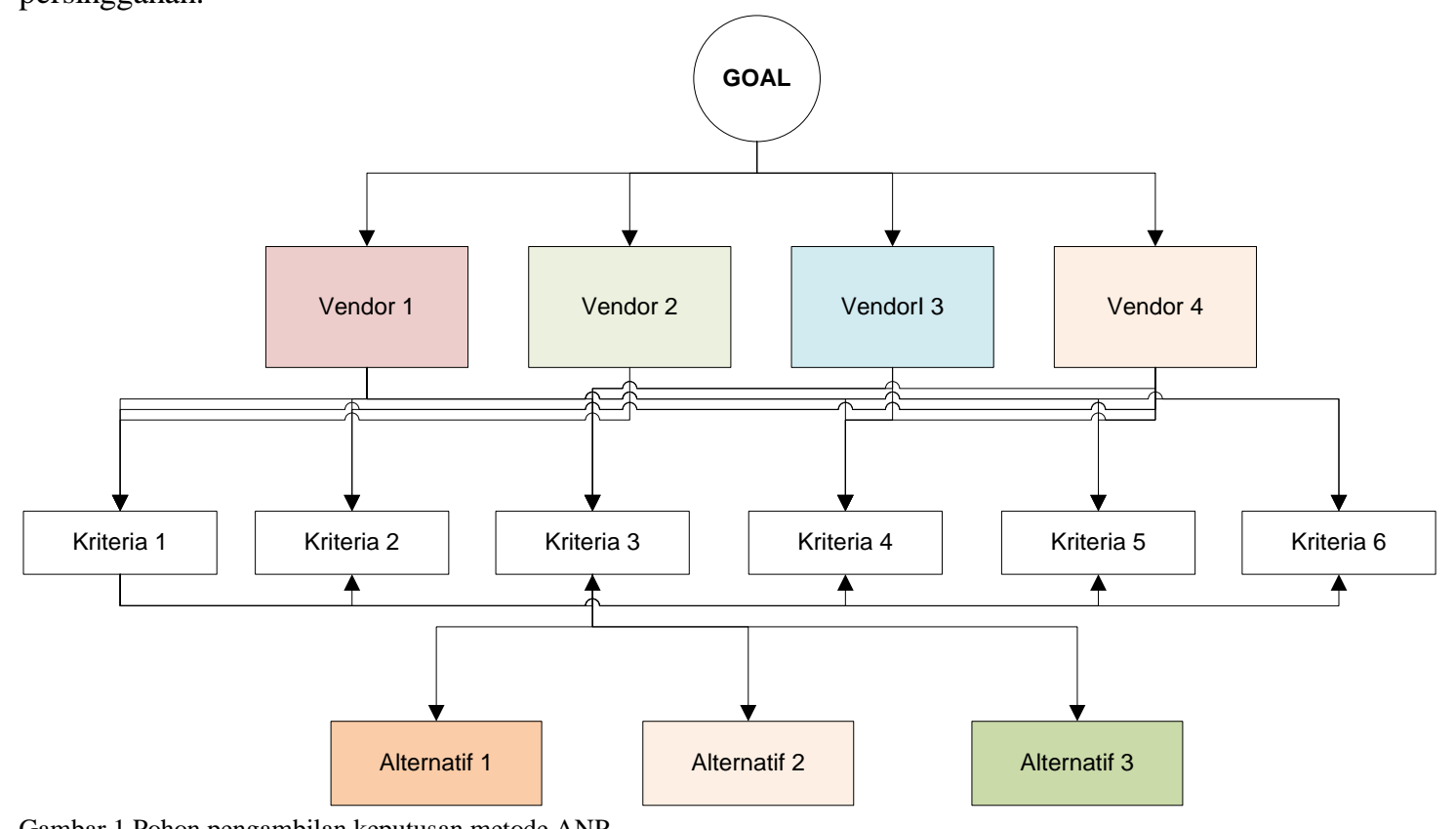

Gambar 1 Pohon pengambilan keputusan metode ANP

mengenai alur pengerjaan tugas akhir.

\section{METODOLOGI}

Luaran yang dihasilkan berupa alur pengadaan perangkat TI dan daftar kriteria vendor TI untuk pondok pesantren.

\section{A. Logika Pengerjaan}

Logika pengerjaan merupakan rancangan terstruktur 


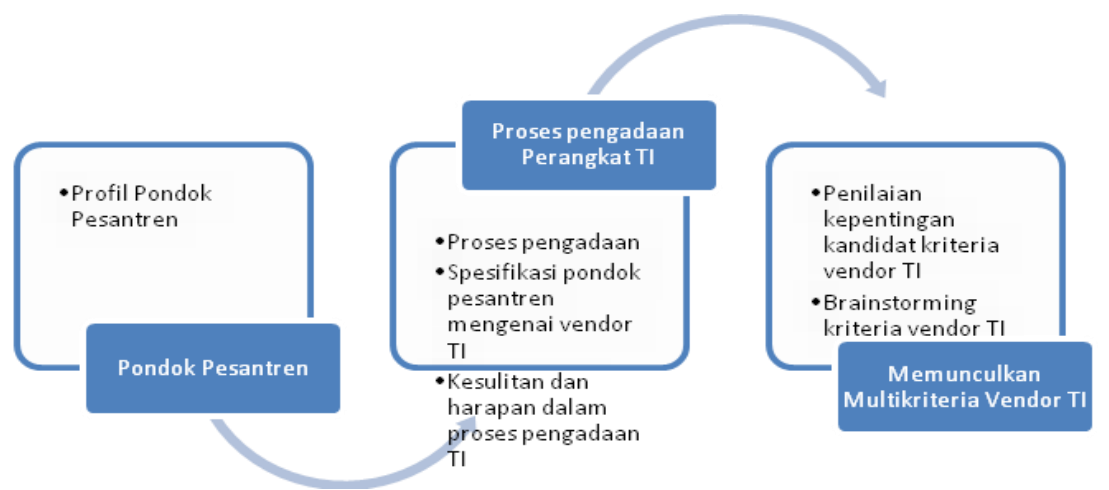

Gambar 2 Logika pengerjaan Tugas Akhir

\section{B. Metodologi}

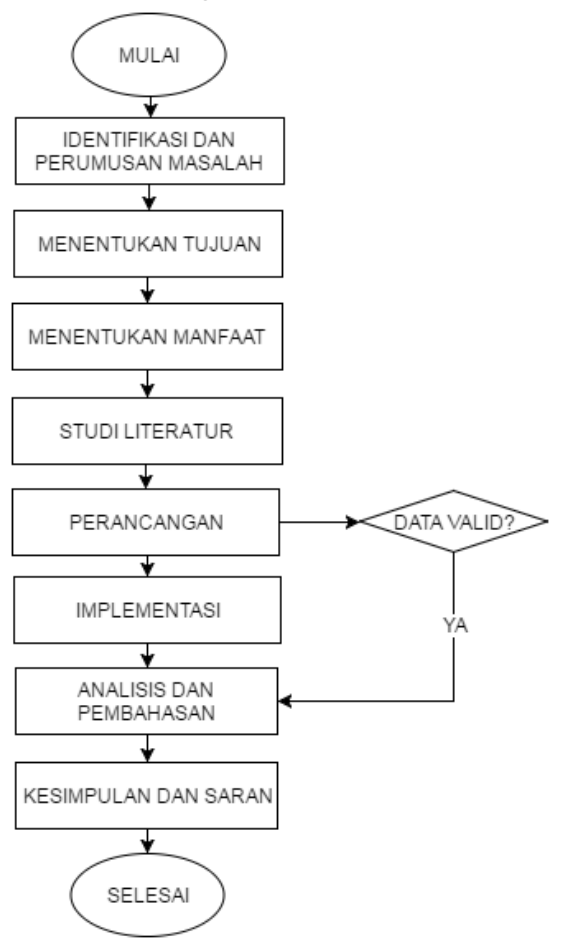

Gambar 3 Metodologi penelitian

\section{PERANCANGAN}

\section{A. Perancangan Penelitian}

Rancangan penelitian yang akan dilakukan adalah dengan melalui dua cara, yaitu:

1. Wawancara

Wawancara merupakan proses menggali informasi secara langsung dari narasumber.

2. Kuesioner

Kuesioner adalah angket yang berisi daftar pertanyaan yang ditujukan kepada seseorang atau kelompok yang bertindak sebagai responden

\section{B. Proses Penelitian}

Pada bagian ini akan menjelaskan mengenai persiapan pengumpulan data pada penelitian tugas akhir ini. Terdapat beberapa metode yang digunakan untuk pengumpulan data, diantaranya wawancara tertulis dan kuesioner.

\section{1) Wawancara Terstruktur}

Wawancara yang akan dilakukan ditujukan kepada interviewer yang bertanggungjawab dalam bidang teknologi informasi yang ada di pondok pesantren. Pertanyaan dibagi menjadi beberapa bagian. Poin-poin tersebut kemudian disusun menjadi sebuah daftar pertanyaan terstruktur.

2) Kuesioner

Kuesioner atau angket juga langsung ditujukan kepada responden.

\section{Objek dan Subjek Penelitian}

Penelitian Tugas Akhir "Penggalian Kriteria Vendor Teknologi Informasi di Pondok Pesantren Mojokerto Jawa Timur" berdasarkan Metode Analytic Network Process dilakukan di tiga pondok pesantren di satu lingkup Kabupaten Kota Mojokerto dengan subjek penanggungjawab atau bagian TI pada pondok pesantren tersebut. Jumlah subjek penelitian satu sampai dua responden yg merupakan penanggungjawab atau bagian TI saja. Objek dari penelitian ini adalah proses pengadaan perangkat TI dan penggalian kriteria vendor TI di pondok pesantren

\section{Strategi Pelaksanaan}

Strategi yang akan dilakukan dalam melakukan penelitian adalah dengan cara wawancara tertulis dan kuesioner yang berfokus pada proses pembelian atau pengadaan perangkat teknologi informasi dan penggalian kriteria vendor TI yang akan menjadi acuan dalam pengadaan TI di pondok pesantren. Penelitian dilakukan di tiga pondok pesantren yang ada di Kabupaten Mojokerto Jawa Timur

\section{IMPLEMENTASI}

\section{A. Proses Pelaksanaan Penelitian}

Pelaksanaan dilakukan dalam kurun waktu satu sampai dengan dua minggu untuk mendapatkan data mengenai proses pengadaan penggalian kriteria vendor teknologi informasi yang sesuai untuk pondok pesantren.

\section{B. Penerapan Strategi Pelaksanaan \\ 1) Hasil Wawancara Tertulis}

Berdasarkan perancangan studi kasus mengenai proses pengadaan perangkat TI dan penggalian kriteria vendor TI dipondok pesantren dengan interviewer pihak pengambil keputusan atau orang yang menangani langsung dalam bidang 
TI di pondok pesantren, maka hasilnya dapat diuraikan kedalam beberapa poin berikut:

1. Sekilas profil pondok pesantren

2. Pondok pesantren dan teknologi informasi

3. Proses pengadaan perangkat teknologi informasi di pondok pesantren

4. Spesifikasi pondok pesantren mengenai vendor teknologi informasi

5. Kesulitan dalam proses pengadaan perangkat teknologi informasi

6. Harapan dalam proses pengadaan perangkat teknologi informasi

2) Hasil Kuesioner

2A Draft hasil kuesioner dengan pertanyaan multiple choice masing-masing pertanyaan didefinisikan dengan skala angka yang berbeda tergantung dengan banyak pilihan jawaban yang disediakan.

2B Hasil penilaian kandidat kriteria berisi urutan kriteria berdasarkan rangking nilai tertinggi. Skala yang digunakan adalah skala Saaty pada metode Analytic Network Process.

2C Berisi daftar kriteria vendor yang menjadi harapan pondok pesantren.

2D Nilai ketergantungan antar kriteria didefinisikan dengan skala 0-1 yaitu ada ketergantungan atau tidak ada ketergantungan antar kriteria yang menjadi perbandingan

\section{Hambatan}

Dalam implementasi perancangan studi kasus terdapat beberapa hambatan yang dialami, diantaranya:

a. Pemilihan dan penetapan tempat pengambilan data. Setiap tempat mempunyai regulasi dan aturan yang berbeda mengenai kebutuhan TI yang mereka terapkan

b. Keterbatasan waktu yang dimiliki oleh pihak objek penelitian. Sehingga proses pengambilan data dilakukan berdasarkan secara langsung dan tidak langsung.

\section{HASIL DAN PEMBAHASAN}

Pada bab ini akan dijelaskan mengenai hasil dari pengolahan data diolah yaitu keluaran dari setiap tahapan dalam metodologi penelitian.

\section{A. Proses Pengadaan/Pembelian Perangkat TI di Pondok Pesantren}

Berdasarkan wawancara tertulis dengan pihak penanggungjawab teknologi informasi di instansi pondok pesantren yang menjadi objek penelitian, proses pembelian atau penadaan perangkat Ti dilakukan secara tradisional, yaitu jika ada kebutuhan untuk melakukan pembelian mereka langsung menuju toko atau pusat perbelanjaan yang menyediakan perangkat TI secara lengkap.

Proses pengadaaan perangkat teknologi informasi dalam tiap instansi dapat disimpulkan melalui urutan proses seperti pada gambar berikut:

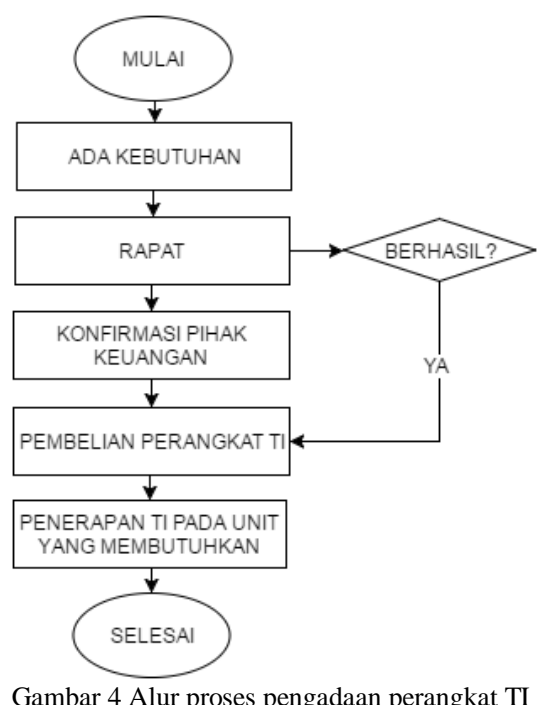

Penjelasan proses pada gambar:

- Penanggungjawab perangkat TI mengidentifikasi apakah ada kebutuhan perangkat TI pada suatu unit tertentu.

- Adanya kebutuhan tersebut kemudian dirapat dengan dewan pengelola.

- Dari hasil rapat, kemudian mengkonfirmasi pihak keuangan apakah tersedia dana saat itu juga guna membeli perangkat TI.

- Jika tersedia dana maka langsung dilakukan proses pembelian, namun jika tidak tersedia dana akan tetapi kebutuhannya bersifat mendesak akan dilakukan peminjaman dana kepada dewan pengurus atau pembina.

\section{B. Penilaian Tingkat Kepentingan Kandidat Kriteria Vendor TI}

Dalam kuesioner, penulis menyajikan beberapa kriteria yang dapat dinilai oleh responden berapa besar tingkat kepentingannya, penilaian tingkat penilaian ini berdasarkan skala Saaty (1-9) pada metode Analytic Network Process. Dari hasil penilaian oleh 6 responden decision maker didapatkan daftar kriteria dengan rangking nilai kepentingan sebagai berikut:

Tabel 1

Rangking kriteria vendor

\begin{tabular}{cclc}
\hline \hline No. & Kode & \multicolumn{1}{c}{ Kriteria } & Rata-rata \\
\hline 1 & $\mathrm{~K}_{1}$ & Harga & 9 \\
2 & $\mathrm{~K}_{3}$ & Kualitas produk & 9 \\
3 & $\mathrm{~K}_{7}$ & Garansi & 8,333333333 \\
4 & $\mathrm{~K}_{2}$ & Potongan harga & 7,333333333 \\
5 & $\mathrm{~K}_{5}$ & Spesifikasi Produk & 7 \\
6 & $\mathrm{~K}_{8}$ & Fasilitas & 7 \\
7 & $\mathrm{~K}_{9}$ & Respon terhadap keluhan & 6,333333333 \\
8 & $\mathrm{~K}_{17}$ & Kemajuan teknologi & 6 \\
9 & $\mathrm{~K}_{15}$ & Kepercayaan & 5,333333333 \\
10 & $\mathrm{~K}_{19}$ & Reputasi vendor & 5,333333333 \\
11 & $\mathrm{~K}_{11}$ & Ketersediaan barang & 4,666666667 \\
12 & $\mathrm{~K}_{4}$ & Karakteristik produk & 4,333333333 \\
13 & $\mathrm{~K}_{6}$ & Keterbukaan terhadap keluhan & 4,333333333 \\
14 & $\mathrm{~K}_{21}$ & Orientasi internasional & 4,333333333 \\
15 & $\mathrm{~K}_{16}$ & Fleksibilitas & 3,333333333 \\
16 & $\mathrm{~K}_{22}$ & Manajemen \& organisasi & 3 \\
17 & $\mathrm{~K}_{14}$ & Kemampuan teknis & 2,666666667 \\
\hline \hline
\end{tabular}




\begin{tabular}{cclc}
\hline \hline 18 & $\mathrm{~K}_{24}$ & Lokasi vendor & 2,666666667 \\
19 & $\mathrm{~K}_{12}$ & Pembungkusan (Packaging) & 2,333333333 \\
20 & $\mathrm{~K}_{13}$ & Pengiriman & 2 \\
21 & $\mathrm{~K}_{20}$ & Kekuatan pasar & 2 \\
22 & $\mathrm{~K}_{10}$ & Cara pembayaran & 1,6666666667 \\
23 & $\mathrm{~K}_{23}$ & Perubahan budaya perusahaan & 1,666666667 \\
24 & $\mathrm{~K}_{18}$ & Sejarah perusahaan & 1,333333333 \\
\hline \hline
\end{tabular}

Dari 24 kandidat kriteria yang disajikan kepada responden, 5 kriteria yang mempunyai nilai tingkat kepentingan tertinggi yaitu harga, kualitas produk, garansi, spesifikasi dan fasilitas yang diberikan oleh vendor

\section{Kriteria Harapan}

Kriteria harapan ini didapatkan dari hasil brainstormin kriteria pada kuesioner. Kriteria harapan tersebut berisi kriteria vendor yang menjadi harapan dari responden yang mewakili pihak pondok pesantren.

Tabel kriteria pemilihan vendor TI yang menjadi harapan oleh Pondok Pesantren adalah sebagai berikut:

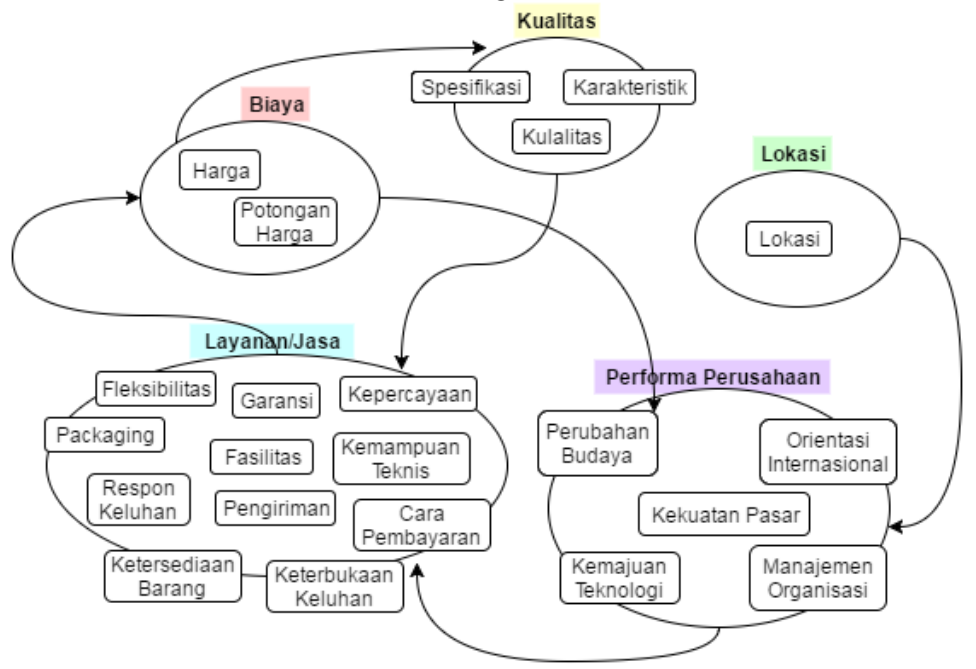

Gambar 5 Hubungan ketergantungan antar kriteria

Masing-masing kriteria mempunyai hubungan ketergantungan.

E. Proses Penentuan Vendor TI Berdasarkan Metode Analytic Network Process

Proses penentuan vendor dengan metode Analytic Network Process sebagaimana telah dijelaskan pada dasar teori, yang dapat digambarkan sebagai berikut:

Tabel 3

Proses penentuan vendor TI berdasarkan metode ANP

\begin{tabular}{cll}
\hline \hline No. & \multicolumn{1}{c}{ Proses } & \multicolumn{2}{c}{ Hasil } \\
\hline 1 & Mendefinisikan masalah & Pemilihan vendor TI berdasarkan \\
& dan menentukan solusi & multi kriteria \\
2 & Pemilihan vendor TI & Kandidat beberapa vendor \\
3 & $\begin{array}{l}\text { Mengidentifikasi kriteria } \\
\text { dan subkriteria }\end{array}$ & Terdapat 5 kandidat kriteria yang \\
& & dibreakdown menjadi 24 subkriteria. \\
& Kriteria tersebut antara lain: \\
& Biaya \\
& Harga \\
& Potongan harga \\
& Kualitas \\
& Kualitas produk \\
& Karakteristik Produk \\
& Spesifikasi Produk \\
\hline
\end{tabular}

Tabel 2

Daftar kriteria harapan

\begin{tabular}{|c|c|c|c|c|}
\hline \multirow{2}{*}{ No. } & \multicolumn{4}{|c|}{ Daftar Kriteria Vendor } \\
\hline & P1 & P2 & P3 & \\
\hline 1. & $\begin{array}{l}\text { Spesifikasi minimal } \\
\text { ternenuhi }\end{array}$ & Berpredikat baik & Dikenal um & \\
\hline 2. & $\begin{array}{l}\text { Memenuhi } \\
\text { kebutuhan }\end{array}$ & $\begin{array}{l}\text { Sesuai dengan } \\
\text { anggaran dana }\end{array}$ & $\begin{array}{l}\text { Memenuhi } \\
\text { kebutuhan } \\
\text { sekolah }\end{array}$ & TI di \\
\hline 3. & $\begin{array}{l}\text { Sesuai dengan } \\
\text { ketersediaan dana }\end{array}$ & $\begin{array}{l}\text { Memenuhi } \\
\text { kebutuhan TI }\end{array}$ & $\begin{array}{l}\text { Sesuai } \\
\text { anggaran } \\
\text { tersedia }\end{array}$ & $\begin{array}{r}\text { dengan } \\
\text { yang }\end{array}$ \\
\hline 4. & Berkualitas & $\begin{array}{l}\text { Sesuai dengan } \\
\text { spesifikasi }\end{array}$ & $\begin{array}{l}\text { Vendor } \\
\text { kualitasnya }\end{array}$ & dikenal \\
\hline 5. & Desain ergonomis & & Mudah dida & atkan \\
\hline
\end{tabular}

\section{Tingkat Ketergantungan antar Kriteria}

Tingkat ketergantungan antar kriteria berdasarkan penilaian oleh responden diilustrasikan seperti pada gambar di bawah ini. 


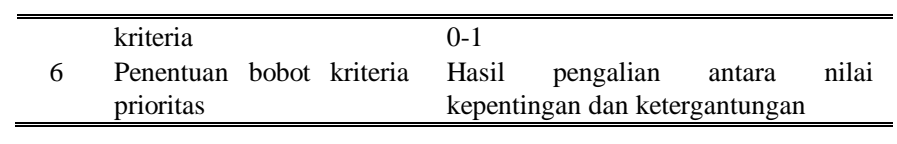

\section{KESIMPULAN}

Proses pengambilan keputusan pemilihan vendor TI melibatkan sejumlah kriteria. Dari 24 kriteria yang diajukan, terdapat 5 kriteria utama yang mempunyai nilai tingkat kepentingan tertinggi yaitu harga dengan nilai kepentingan 9, kualitas produk 9, garansi 8.33 , spesifikasi 7.33 dan fasilitas yang diberikan oleh vendor dengan nilai tingkat kepentingan 7 . Sedangkan untuk kriteria yang menjadi harapan antara lain predikat vendor dan pamor atau vendor dikenal luas oleh khalayak.

Pemilihan vendor TI tidak hanya bertumpu pada ketersediaan dana di pondok pesantren tersebut, akan tetapi juga memperhatikan sejumlah kriteria lainnya sebagaimana dalam perangkingan kandidat kriteria vendor yaitu harga sebagai pilihan utama kemudian kualitas produk, garansi, spesifikasi dan fasilitas yang diberikan oleh vendor tersebut.

\section{UCAPAN TERIMA KASIH}

Penulis menyampaikan terima kasih kepada semua pihak yang terlibat dalam penyelesaian tugas akhir. Bapak dan Ibu dosen pembimbing serta penguji. Kementrian Agama RI. Community Santri Scholar of Ministry of Religious Affairs ITS. Bapak dan Ibu dosen serta karyawan Jurusan Sistem Informasi. Karyawan dan civitas Fakultas Teknologi Informasi ITS dan juga teman-teman seperjuangan.

\section{DAFTAR PUSTAKA}

[1] N. Madjid, Bilik-Bilik Pesantren, Sebuah Potret Perjalanan, Jakarta: Paramadina, 1997, p. 5.

[2] I. A. Sandy, Alfian and M. G. A. P, "Penerapan Metode Analytic Network Process (ANP) untuk Pemilihan Supplier Bahan Baku pada CV TX," Seminar Nasional IENACO, p. 1, 2013.

[3] F. Metandi and S. Hartati, "Sistem Pendukung Keputusan Pemilihan Vendor dengan Metode ANP dan TOPSIS," p. 1, 2013.

[4] T. L. Saaty, Decision Making with Dependence and Feedback: The Analytic Network Process, Pittburgh, USA: RWS Publication, 4922 Ellsworth Avenue, 2001. 